\title{
PERBEDAAN KECERDASAN SPASIAL ANTARA SISWA LAKI-LAKI DAN SISWA PEREMPUAN KELAS X SMA YPK MEDAN PADA MATERI GEOMETRI
}

\author{
Suci Dahlya Narpila \\ Universitas Potensi Utama, Medan \\ Email:suci.dahlya@gmail.com
}

\begin{abstract}
This research stems from the writer's curiosity about the difference of spatial intelligence between male and female students in SMA YPK Medan. The purpose of this research was to describe data of the difference of spatial intelligence between male and female students. This research was a comparative causal research. The sample of this research were 65 students of SMA YPK Medan, which consisted of 32 were female students and 33 were male students. Data to be collected in this research was the data of student's spatial intelligence which were grouped, i.e. the data of female students spatial intelligence and the data of male students spatial intelligence. The data were collected then analyzed by independent samples t-test in SPSS program. From result of SPSS obtained data Sig 0,02 <0,05. Based on the result of data analysis could be conluded that there were the difference of spatial intelligence between male and female students in SMA YPK Medan. The average spatial intelligence of male students were 27,06 higher than the average spatial intelligence of female students were 26,76. Then it could be concluded the spatial intelligence of male students better than the spatial intelligence of female students.
\end{abstract}

Keywords : Spatial intelligence, Gender, Geometry

\section{PENDAHULUAN}

Hasil penelitian PISA tahun 2006 (dalam Purwanti, 2013) menyatakan bahwa rata-rata kemampuan matematika siswa lakilaki lebih tinggi 17 poin daripada siswa perempuan. Dimana rata-rata kemampuan siswa laki-laki mencapai skor 399 dan siswa perempuan mencapai skor 382. Berdasarkan hal ini, berarti terdapat kecenderungan perbedaan kemampuan laki-laki dan perempuan dalam hasil belajar, terutama dalam bidang matematika dan sains.

Perbedaan tersebut disebabkan oleh faktor psikologis. Secara psikologis, laki-laki dan perempuan memiliki banyak perbedaan terkait inetelegensi, minat, bakat, motivasi, kematangan atau kesiapan. Kartono (1989) berpendapat bahwa pada intinya perempuan hampir tidak pernah mempunyai ketertarikan yang menyeluruh pada soal teoritis seperti laki-laki, perempuan lebih tertarik pada hal yang praktis daripada teoritis. Perempuan juga lebih dekat pada masalah kehidupan yang praktis konkret, sedangkan laki-laki pada segi yang abstrak.

Hal senada juga diungkapkan oleh Krutetski dalam Nafi'an (2011) menjelaskan perbedaan laki-laki dan perempuan dalam belajar matematika adalah : (1) laki-laki lebih unggul dalam penalaran, perempuan lebih unggul dalam ketepatan, ketelitian, kecermatan dan keseksamaan berpikir; (2) laki-laki memiliki kemampuan matematika dan mekanika yang lebih baik daripada perempuan, perbedaan ini kurang terlihat pada tingkat sekolah dasar akan tetapi menjadi tampak lebih jelas pada tingkat yang lebih tinggi. Pendapat ini menunjukkan bahwa laki-laki memiliki kemampuan lebih baik dalam bidang matematika, sedangkan perempuan akan menonjol dalam bidang afektif.

Sementara itu, Maccoby dan Jacklin (1974) menyatakan bahwa laki-laki dan perempuan mempunyai perbedaan kemampuan yaitu (1) perempuan mempunyai kemampuan verbal lebih tinggi daripada laki-laki; (2) lakilaki lebih unggul dalam kemampuan visual spasial (penglihatan dan keruangan) daripada perempuan dan (3) laki-laki lebih unggul dalam kemampuan matematika. Menurut Nafi'an (2011) perbedaan gender ini bukan hanya berakibat pada perbedaan kemampuan matematika, tetapi juga berpengaruh pada bagaimana pengetahuan matematika itu didapat.

Berbagai fakta di atas menunjukkan bahwa memang terdapat perbedaan kemampuan matematika laki-laki dan 
perempuan. Perbedaan itu akan sangat terlihat jelas dalam salah satu jenis kemampuan matematika, yang juga merupakan salah satu dari tujuh kecerdasan yang dimiliki oleh manusia, yaitu kecerdasan spasial.

Gardner (dalam Bosnyak, 2008) menyatakan bahwa : "spatial intelligence is the ability of forming a mental model of the spatial world and manoeuvring and working with this model". Hal ini menjelaskan bahwa kemampuan spasial adalah kemampuan mengenai ruang atau dimensi tiga, menafsirkan atau membuat model tertentu dari ruang tersebut dan kemudian menyelesaikan permasalahan mengenai ruang dengan cepat dan tangkas. Pengertian ini menekankan bahwa kemampuan spasial adalah menunjukkan kemampuan mengenai keruangan, dimensi tiga atau lebih tepatnya bangun ruang. Kemampuan tersebut bisa memahami unsur atau definisi bangun ruang tertentu atau menyelesaikan permasalahan yang terdapat dalam bangun ruang itu.

Kecerdasan spasial merupakan salah satu aspek dari kognisi. Thurstone (dalam Barke, 2001) menyatakan bahwa kemampuan spasial merupakan salah satu kemampuan yang penting dari beberapa kecerdasan yang dimiliki oleh manusia. Kemampuan membayangkan suatu bentuk nyata dan kemudian memecahkan berbagai masalah yang berhubungan dengan kemampuan ini adalah hal yang menonjol pada jenis kemampuan spasial ini.

Dalam matematika kecerdasan spasial ini sangat erat kaitannya dengan materi geometri. Geometri sendiri merupakan ilmu yang mempelajari bentuk, garis dan ruang yang ditempati. Setidaknya ada dua bagian utama dalam materi geometri, yaitu bentuk dimensi dua dan dimensi tiga (Ismunanto, 2015).

Chatib dan Said (2012) menyatakan bahwa belajar geometri tidak terlepas dari mengenal bentuk, warna dan detail, kepekaan merasakan dan membayangkan dunia gambar dan ruang secara akurat, menggunakan gambar visual sebagai alat bantu dalam mengingat informasi, membaca grafik, bagan, peta dan diagram. Hal ini menjelaskan bahwa untuk mempelajari geometri membutuhkan kecerdasan spasial.

Selain menunjang kemampuan matematika, kecerdasan spasial merupakan hal yang penting dalam berbagai pekerjaan. Dalam National Academy of Science (dalam Syahputra, 2013) dikatakan bahwa banyak bidang ilmu yang membutuhkan kemampuan spasial dalam penerapan ilmu tersebut antara lain astronomi, pendidikan, geografi, geosciences, dan psikologi. Nemeth (2007) dalam penelitiannya menemukan pentingnya kemampuan spasial pada ilmu-ilmu teknik dan matematika khususnya geometri.

Maier (1998) membagi kecerdasan spasial menjadi lima aspek yang kemudian dapat dirancang suatu indikator kemampuan spasial dalam Tabel 1 berikut :

Tabel 1. Indikator Kemampuan Spasial

\begin{tabular}{cll}
\hline Aspek Spasial & \multicolumn{1}{c}{ Uraian } & Indikator \\
\hline Spatial & Kemampuan & Dapat \\
perception & untuk mengenal & menyatakan \\
& bahwa ukuran & bentuk atau \\
& dan bentuk & ukuran yang \\
& subjek tetap & sebenarnya \\
& walaupun & dari suatu \\
& stimulusnya & tampilan \\
& berbeda yang & dimensi tiga \\
& didasarkan pada & yang \\
& apa yang kita & berdasarkan \\
& rasakan dari & perspektif \\
& perspektif & tertentu \\
& tersebut & \\
Visualisation & Kemampuan & Dapat \\
& membayangkan & menyatakan \\
& suatu perubahan & kondisi \\
& bentuk dari suatu & (bentuk) yang \\
& obek atau & sebenarnya \\
& perubahan & dari suatu \\
& susunan bagian & perubahan \\
& dari suatu objek. & susunan atau \\
& & bagian objek \\
& & tertentu \\
Spatial & Kemampuan & Dapat \\
& Suatu & Dapat \\
& kemampuan & menyatakan \\
& berpikir secara & bentuk atau \\
& cepat dan tepat & posisi suatu \\
& mengenai rotasi & bangun ruang \\
& pada objek 2 & sebagai \\
dimensi atau 3 & akibat dari \\
& dimensi & rotasi \\
& & \\
& & \\
& & \\
& &
\end{tabular}


PRINSIP Pendidikan Matematika

Volume 2, Nomor 1, November 2019

$\begin{array}{cll}\text { Relation } & \text { memahami } & \text { menyatakan } \\ & \text { bentuk suatu } & \text { hubungan } \\ \text { objek atau } & \text { unsur-unsur } \\ \text { bagian dari suatu } & \text { dalam } \\ \text { objek dan } & \text { dimensi 3 } \\ & \text { hubungan antar } & \text { (hubungan } \\ & \text { bagian objek } & \text { garis, bidang, } \\ & \text { tersebut } & \text { dan titik) } \\ \text { Spatial } & \text { Kemampuan } & \text { Dapat } \\ \text { mengenal } & \text { menyatakan } \\ & \text { susunan atau } & \text { bentuk suatu } \\ & \text { bentuk suatu } & \text { objek jika } \\ & \text { objek pada } & \text { dilihat dari } \\ & \text { perspektif dan } & \text { berbagai } \\ & \text { situasi tertentu } & \text { perspektif } \\ & & \text { dan situasi } \\ & & \text { tertentu }\end{array}$

Kecerdasan spasial menjadi salah satu faktor yang menentukan kemampuan matematika siswa. Diungkapkan oleh Benbov dan Stanley (Orton, 1992), gender sangat mempengaruhi kemampuan matematika seseorang. Kemampuan matematika laki-laki lebih unggul daripada perempuan. Laki-laki memiliki kemampuan yang tinggi pada kemampuan spasial (keruangan), sehingga siswa laki-laki dalam topik tertentu akan memperoleh skor yang lebih tinggi dibandingkan dengan skor siswa perempuan, seperti pada topik pecahan, geometri dan masalah ilmu ukur ruang, sedangkan perempuan lebih baik pada kemampuan verbal.

Hal ini lebih ditekankan pada penelitian McGee (dalam Tambunan, 2006), kemampuan matematika siswa laki-laki lebih baik daripada siswa perempuan dikarenakan siswa laki-laki memiliki kemampuan spasial yang jauh lebih baik daripada siswa perempuan. Berdasarkan pendapat para ahli tersebut, perempuan lemah dalam persoalan abstrak, yang mengakibatkan perempuan dianggap lemah dan kurang mampu dalam mempelajari matematika terutama dalam bidang geometri, karena geometri terdiri dari objek yang abstrak.

Windratie (2014) dalam artikelnya menyatakan bahwa sebuah penelitian di Swedia menemukan bahwa multitasking pada laki-laki sebenarnya lebih baik dari perempuan saat melibatkan tugas-tugas spasial (kemampuan mengenal hubungan berbagai bentuk gambar). Ini artinya anak laki-laki dapat lebih baik melakukan berbagai pekerjaan sekaligus untuk pekerjaan yang berkaitan dengan tugas-tugas spasial.

Begitu juga dengan kompasiana dalam artikelnya menyatakan bahwa sekitar 50\% perempuan tidak bisa menunjuk mana kanan dan mana kiri ketika ditanya secara mendadak. Sementara itu laki-laki memiliki struktur otak yang membuatnya hebat dalam kemampuan spasial, seperti kemampuan navigasi dan menyetir mobil. Hanya $10 \%$ perempuan yang memiliki kemampuan ruang (spasial) yang sama baiknya dengan laki-laki.

Springer \& Deuthsch (dalam Battista, 1990) memandang perbedaan gender dalam kemampuan geometri ini secara berbeda. Semakin besar tingkat laterisasi (spesialisasi pada satu otak kanan), maka semakin baik kecerdasan spasialnya. Sehingga berdasarkan fungsi salah satu bagian otak, memang lakilaki akan lebih unggul pada pekerjaan yang berhubungan kecerdasan spasial.

Tidak semua penelitian menyimpulkan bahwa kemampuan spasial laki-laki lebih baik dari kemampuan spasial perempuan. Lean \& Clemens (Tambunan, 2006) menyatakan bahwa tidak ada hubungan antara kecerdasan spasial dengan matematika. Sedangkan Asis, dkk (2015) menyatakan bahwa tidak ada perbedaan kecerdasan spasial antara anak lakilaki dan anak perempuan dalam hal menyelesaikan masalah.

Selain dua penelitian di atas, jika dilihat pada realitas kehidupan, maka beberapa kasus justru menunjukkan bahwa perempuan juga memiliki kecerdasan spasial yang tidak kalah baik disbanding laki-laki. Hal ini dapat dilihat dari terdapatnya beberapa profesi yang memerlukan kecerdasan spasial namun dapat dilakukan oleh perempuan.

Menurut American Psychological Association (dalam Lestari, 2010), berdasarkan analisis terbaru dari penelitian internasional kemampuan perempuan di seluruh dunia dalam matematika tidak lebih buruk daripada kemampuan laki-laki, meskipun laki-laki memiliki kepercayaan diri yang lebih baik dari perempuan dalam matematika.

Realita di lapangan menunjukkan bahwa kecerdasan spasial siswa juga berbeda pada siswa perempuan dan siswa laki-laki. Hal ini dibuktikan dari tes kecerdasan spasial yang 
diberikan kepada siswa kelas XII IPA SMA YPK Medan. Dari hasil jawaban siswa diperoleh bahwa hanya 15 orang siswa yang menyelesaikan soal ini dengan benar dari 38 siswa yang mengikuti tes tersebut. Artinya, hanya ada 39,5 \% siswa yang bisa menyelesaikan soal ini dengan benar, 60, 5\% siswa lainnya menjawab salah. Dari 15 orang yang menjawab benar itu hanya 5 orang perempuan dan 10 lainnya adalah laki-laki.

Hal ini diperkuat dengan wawancara dengan guru matematika SMA YPK Medan. Ia menjelaskan bahwa siswa mengalami kesulitan ketika disuruh untuk mengimajinasikan sebuah bangun ruang dengan sebuah titik, garis atau bidang, terutama siswa perempuan. Hal ini kembali menegaskan bahwa terdapat kecenderungan perbedaan kemampuan spasial siswa laki-laki dan perempuan.

Berdasarkan hasil-hasil penelitian yang diuraikan di atas menunjukkan bahwa adanya keberagaman hasil penelitian mengenai peran gender dalam pembelajaran matematika, khususnya pada kecerdasan spasial. Beberapa hasil penelitian menunjukkan adanya faktor gender dalam pembelajaran matematika, namun pada sisi lain beberapa penelitian mengungkapkan bahwa gender tidak berpengaruh secara signifikan dalam pembelajaran matematika. Oleh karena itu, penelitian ini dilakukan untuk mengetahui ada tidaknya perbedaan kecerdasan spasial antara siswa laki-laki dan perempuan pada materi geometri di kelas X SMA YPK Medan.

\section{METODE}

Pendekatan penelitian ini adalah pendekatan kuantitatif. Pendekatan kuantitatif merupakan pengujian suatu teori dengan cara menguji hipotesis yang spesifik, mengumpulkan data-data yang mendukung atau membantah hipotesis tersebut (Creswell, 2010).

Populasi dalam penelitian ini adalah seluruh siswa kelas X SMA YPK Medan yang berjumlah 234 siswa yang terbagi menjadi 4 kelas dengan 2 kelas jurusan IPA dan 2 kelas jurusan IPS. Adapun sampel dalam penelitian ini terdiri dari dua kelas yaitu kelas X IPA 1 dan X IPA 2 yang berjumlah 65 siswa.

Adapun alasan memilih kelas $\mathrm{X}$ ini adalah merujuk kepada teori perkembangan kognitif Piaget yang menyatakan bahwa anak pada rentang usia 11 tahun sampai dewasa akan memasuki periode operasi formal. Siswa kelas X rata-rata akan berada pada interval usia ini, sehingga siswa kelas $\mathrm{X}$ ini akan memasuki periode operasi formal. Sehingga berdasarkan teori perkembangan kognitif piaget (dalam Simatwa dan Enose, 2010), pada tahap ini seorang anak mampu berpikir logis untuk semua jenis masalah hipotesis, dan ia dapat menggunakan penalaran ilmiah dan dapat menerima pandangan orang lain.

Penelitian diawali dengan penyusunan tes kecerdasan spasial. Tes disusun berdasarkan aspek yang kecerdasan spasial yang telah ditetapkan. Selanjutnya tes ini divalidasi oleh para ahli. Hasil validasi ini diujicoba kepada kelas non sampel. Tujuan uji coba ini adalah untuk mengetahui kelayakan dari tes yang diberikan kepada sampel.

Setelah tes dinyatakan layak, tes kecerdasan spasial ini diujicobakan kepada sampel, kemudian dihitung skor per masingmasing siswa. Skor tersebut dibagi ke dalam dua kelompok yaitu kelompok laki-laki dan kelompok perempuan. Setelah itu peneliti akan melakukan uji prasyarat untuk pengujian hipotesis, diantaranya uji normalitas, uji homogenitas, dan uji perbedaan rata-rata.

Data yang dikumpulkan adalah data kecerdasan spasial siswa. Data tersebut diperoleh dari tes kecerdasan spasial siswa. Tes kecerdasan spasial ini berbentuk soal uraian yang terdiri dari 4 butir soal. Penyusunan soal dimulai dengan pembuatan kisi-kisi soal yang mencakup pokok bahasan geometri dan aspek kecerdasan spasial. Berikut kisi-kisi tes kecerdasan spasial siswa :

Tabel 2. Kisi-Kisi Tes Kecerdasan Spasial

\begin{tabular}{|c|c|c|}
\hline $\begin{array}{c}\text { Aspek } \\
\text { Kemampuan } \\
\text { Spasial }\end{array}$ & $\begin{array}{l}\text { Indikator Soal Tes } \\
\text { Kemampuan Spasial }\end{array}$ & $\begin{array}{c}\text { Nomor } \\
\text { Soal }\end{array}$ \\
\hline $\begin{array}{c}\text { Spatial } \\
\text { Perception }\end{array}$ & $\begin{array}{l}\text { Menentukan balok } \\
\text { yang memiliki diagonal } \\
\text { ruang yang sama jika } \\
\text { diberikan beberapa } \\
\text { balok tertentu }\end{array}$ & 1 \\
\hline Relations & $\begin{array}{l}\text { Menentukan nilai } \\
\text { kebenaran dari suatu } \\
\text { pernyataan mengenai }\end{array}$ & $3 a$ \\
\hline
\end{tabular}




\begin{tabular}{cll} 
& & \\
& jarak titik ke garis jika & \\
& diberikan suatu kubus & \\
& dengan ukuran tertentu. & \\
Mental & Menentukan jarak titik & $3 \mathrm{~b}$ \\
Rotation & ke bidang pada suatu & \\
& bangun setelah bangun & \\
& itu diputar & \\
Visualisation & Menentukan jarak garis & 2a \\
& ke garis jika diberikan & \\
& suatu jaring-jaring \\
& kubus \\
& Menentukan jarak garis & \\
& ke bidang jika \\
& diberikan suatu jaring- \\
& jaring kubus \\
& Menentukan jarak \\
& bidang hijau dan \\
& bidang kuning pada \\
& suatu balok tertentu \\
\hline
\end{tabular}

Sebelum tes kecerdasan ini digunakan dalam penelitian, terlebih dahulu dilakukan validasi dan uji coba. Validasi dilakukan melalui pendapat beberapa ahli yang berasal dari dosen dan guru. Proses validasi ini dimaksudkan agar mendapat saran terhadap perbaikan tes kecerdasan spasial. Setelah divalidasi, perangkat pembelajaran akan diujicobakan pada siswa yang berada di luar sampel penelitian. Dari hasil ujicoba ini akan didapat masukan mengenai penggunaan tes kecerdasan spasial. Setelah diujicobakan, hasil uji coba akan dianalisis secara statistik untuk mengetahui validitas dan realibilitas.

Untuk menghitung validitas butir soal pada instrumen penelitian ini, digunakan rumus korelasi Product Momen Pearson yaitu

$$
r_{x y}=\frac{N \sum X Y-\left(\sum X\right)\left(\sum Y\right)}{\sqrt{\left.\left\{N \sum X^{2}-\left(\sum X\right)^{2}\right\} N \sum Y^{2}-\left(\sum Y\right)^{2}\right\}}}
$$

(Sugiyono, 2010)

Sedangkan rumus yang digunakan untuk mencari koefisien reliabilitas bentuk uraian dikenal dengan rumus Cronbach`s Alpha yaitu:

$$
r_{i}=\left(\frac{k}{k-1}\right)\left(1-\frac{\sum s_{i}^{2}}{s_{t}^{2}}\right)
$$

(Sugiyono, 2010)
Adapun teknik analisis data yang digunakan dalam penelitian adalah analisis data kuantitatif berupa hasil tes kecerdasan spasial siswa. Hasil tes kecerdasan spasial ini akan dikelompokkan berdasarkan kelompok laki-laki dan perempuan. Selanjutnya akan dilakukan uji prasyarat dalam pengujian hipotesis, yaitu uji normalitas dan uji homogenitas. Uji normalitas dilakukan dengan cara uji Kolmogorov-Smirnov, sedangkan uji homogenitas menggunakan perbandingan varians terbesar dengan varians terkecil yang diperoleh dari kedua kelompok.

Untuk melihat perbedaan kecerdasan spasial laki-laki dan perempuan akan dilakukan uji Independent Samples T-Test. Pengolahan data dilakukan dengan bantuan software SPSS 16.

\section{HASIL DAN PEMBAHASAN}

Tes kecerdasan spasial siswa yang telah disusun berdasarkan kisi-kisi diuji validitas dan realibilitasnya. Berikut hasil validitas dan realibilitas uji coba tes kecerdasan spasial siswa.

Tabel 3. Hasil Validitas Uji Coba Tes Kemampuan Spasial

\begin{tabular}{cllcl}
\hline Soal & \multicolumn{4}{c}{ Validitas } \\
\cline { 2 - 5 } & $\begin{array}{l}\text { Koefisien } \\
\text { Korelasi }\end{array}$ & $\mathbf{t}_{\text {hitung }}$ & $\mathbf{t}_{\text {tabel }}$ & Interpretasi \\
1 & 0,79 & 7,13 & 2,042 & Tinggi/Valid \\
2 & 0,68 & 5,07 & & Tinggi/Valid \\
3 & 0,73 & 5,83 & & Tinggi/Valid \\
4 & 0,60 & 4,10 & & Cukup/Valid \\
\hline
\end{tabular}

Tabel 3 menunjukkan bahwa tes kecerdasan spasial sudah valid dengan koefisien reliabilitas 0,614 dengan kategori tinggi. Berdasarkan hasil ujicoba yang telah dilakukan, diperoleh bahwa tes kecerdasan spasial dapat digunakan sebagai alat ukur untuk mengetahui kecerdasan spasial siswa.

Pengujian normalitas data kecerdasan spasial siswa bertujuan untuk mengetahui apakah data tersebut berdistribusi normal atau tidak. Terlebih dahulu tetapkan hipotesis untuk pengujian normalitas populasi, yaitu:

$H_{0}$ : sampel berasal dari populasi berdistribusi normal

$H_{a}$ : sampel tidak berasal dari populasi berdistribusi normal 
Hasil pengujian normalitas hasil tes kecerdasan spasial siswa dengan menggunakan uji Kolmogorov-Smirnov melalui SPSS 16 disajikan pada Tabel 4 berikut :

Tabel 4. Pengujian Normalitas Hasil Tes Kecerdasan Spasial

\begin{tabular}{|c|c|c|c|c|c|c|}
\hline & \multicolumn{3}{|c|}{ Kolmogorov-Smirnov ${ }^{a}$} & \multicolumn{3}{|c|}{ Shapiro-Wilk } \\
\hline & $\begin{array}{c}\text { Statis } \\
\text { tic }\end{array}$ & df & Sig. & Statistic & df & Sig. \\
\hline Nilai & .095 & 69 & $0.200^{*}$ & .958 & 69 & .21 \\
\hline
\end{tabular}

Kolmogorov Smirnov diperoleh nilai $\mathrm{Sig}=$ $0,200>0,05$, sehingga Ho diterima, yang berarti data berasal dari populasi berdistribusi normal. Untuk uji Shapiro Wilk diperoleh nilai Sig $=0,21>0,05$. Hal ini juga menyatakan bahwa Ho diterima dan Ha ditolak. Dari pengujian normalitas ini didapatkan bahwa data yang diperoleh dari hasil tes kecerdasan spasial siswa berdistribusi normal.

Pengujian homogenitas hasil tes kecerdasan spasial bertujuan untuk mengetahui apakah varians data hasil tes kecerdasan spasial homogen atau tidak. Adapun hipotesis yang akan diuji sebagai berikut.

$H_{0}$ : variansi pada tiap kelompok sama (homogen)

$H_{a}$ : variansi pada tiap kelompok tidak sama (tidak homogen)

Hasil pengujian homogenitas hasil tes kecerdasan spasial dengan menggunakan uji Levene melalui SPSS 16. disajikan pada Tabel 5.

Tabel 5. Pengujian Homogenitas Hasil Tes Kecerdasan Spasial

\begin{tabular}{|c|c|c|c|c|c|}
\hline & & $\begin{array}{l}\text { Levene } \\
\text { Statistic }\end{array}$ & df1 & df2 & Sig. \\
\hline \multirow[t]{4}{*}{ Nilai } & Based on Mean & .099 & 1 & 67 & .755 \\
\hline & $\begin{array}{l}\text { Based } \\
\text { Median }\end{array}$ & .095 & 1 & 67 & .759 \\
\hline & $\begin{array}{l}\text { Based on } \\
\text { Median and with } \\
\text { adjusted df }\end{array}$ & .095 & 1 & $\begin{array}{l}65.59 \\
6\end{array}$ & .759 \\
\hline & $\begin{array}{l}\text { Based on } \\
\text { trimmed mean }\end{array}$ & .085 & 1 & 67 & .771 \\
\hline
\end{tabular}

Berdasarkan Tabel 5 tersebut diperoleh nilai sig pada Based on trimmed mean adalah $0,085>0,05$. Sehingga $\mathrm{H}_{0}$ diterima dan $\mathrm{H}_{\mathrm{a}}$ ditolak. Dengan demikian varians hasil tes kecerdasan spasial siswa homogen.

Dari hasil pengujian normalitas dan homogenitas terbukti bahwa data hasil tes kecerdasan spasial siswa beridistribusi normal dan homogen, sehingga bisa dilanjutkan dengan uji perbedaan rata-rata. Hasil pengujian perbedaan rata-rata hasil tes kecerdasan spasial dengan menggunakan SPSS 16. disajikan pada Tabel 6 :

Tabel 6. Hasil Uji Perbedaan Rata-Rata Hasil Tes Kecerdasan Spasial

\begin{tabular}{llll}
\hline & Gender & N & Mean \\
\hline \multirow{2}{*}{ Nilai } & Laki-laki & 32 & 27.06 \\
& Perempuan & 33 & 26.76 \\
\hline
\end{tabular}

Dari Tabel 6 terlihat kecerdasan spasial 32 siswa laki-laki $(27,06)$ lebih tinggi daripada kecerdasan spasial siswa 33 siswa perempuan $(26,76)$. Hal ini menunjukkan bahwa kecerdasan spasial laki-laki lebih tinggi daripada kecerdasan spasial perempuan.

Selanjutnyan akan dilihat hasil tes kecerdasan spasial dengan menggunakan Independent Samples T-Test. Namun, sebelumnya akan ditetapkan hipotesisnya, yaitu sebagai berikut :

$H_{0}$ : tidak terdapat perbedaan kecerdasan spasial antara siswa laki-laki dan siswa perempuan

$H_{a}$ : terdapat perbedaan kecerdasan spasial antara siswa laki-laki dan siswa perempuan

Hasil pengujian perbedaan rata-rata hasil tes kecerdasan spasial dengan menggunakan Independent Samples T-Test melalui SPSS 16. disajikan pada Tabel 7 berikut.

Tabel 7. Hasil Uji Perbedaan Rata-Rata Hasil Tes Kecerdasan Spasial

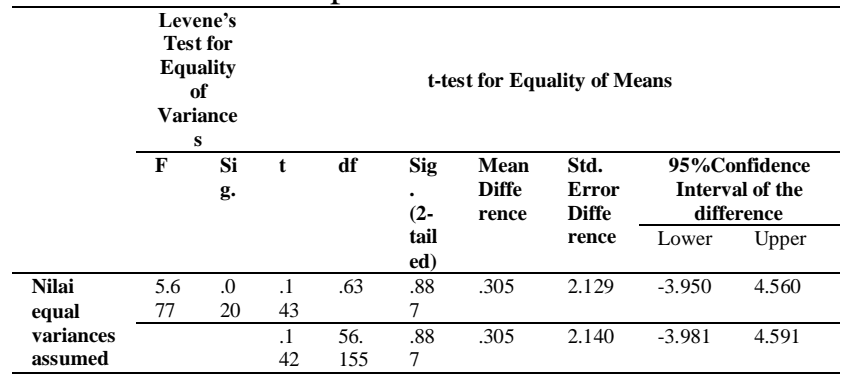

Pada Tabel 7, tampak bahwa nilai sig $(0,02)$ lebih kecil dari 0,05 . Ini artinya $\mathrm{Ha}$ diterima. Artinya terdapat perbedaan kecerdasan spasial antara siswa laki-laki dan siswa perempuan. Karena kecerdasan spasial 
32 siswa laki-laki $(27,06)$ lebih tinggi daripada kecerdasan spasial siswa 33 siswa perempuan $(26,76)$ maka dapat disimpulkan bahwa pada siswa kelas X SMA YPK Medan, kecerdasan spasial siswa laki-laki lebih baik dibandingkan kecerdasan spasial siswa perempuan.

Perbedaan kecerdasan spasial tersebut disebabkan oleh banyak hal, salah satunya dari aspek biologis. Banyak penelitian telah membuktikan bahwa terdapat perbedaan fisik antara laki-laki dan perempuan. Pada jaringan tertentu, perkembangan otak laki-laki lebih tinggi daripada perempuan terutama yang berkaitan dengan aktivitas berpikir. Secara fungsional pun, lelaki dan perempuan juga memiliki perbedaan. Misalnya saja laki-laki yang mempunyai jarak penglihatan yang lebih baik dan persepsi yang lebih mendalam dibandingkan perempuan. Hal inilah yang kemudian dapat membantu laki-laki menyelesaikan hal-hal yang berhubungan dengan spasial secara tepat. Secara psikologis juga sama, terdapat perbedaan yang signifikan antara cara berpikir siswa laki-laki dan siswa perempuan. Menurut Bratama (1987) perempuan pada umumnya lebih baik pada ingatan dan laki-laki lebih baik dalam berpikir logis. Perempuan cenderung pada hal yang konkret, sedangkan laki-laki lebih tertarik pada hal yang bersifat abstrak.

Hasil dari penelitian ini sejalan dengan penelitian Handayani, dkk (2016) yang menyatakan bahwa kecerdasan spasial siswa laki-laki lebih baik dari kecerdasan spasial perempuan pada kelas X SMA Negeri 1 Salatiga. Adanya perbedaan antara kemampuan spasial siswa laki-laki dan siswa perempuan dipengaruhi oleh perbedaan perilaku, perkembangan dan pemrosesan kognitif antara laki-laki dan perempuan.

\section{SIMPULAN}

Beberapa uraian pada hasil penelitian menunjukkan bahwa terdapat perbedaan kecerdasan spasial siswa laki-laki dan siswa perempuan di kelas X SMA YPK Medan.dimana kemampuan spasial laki-laki lebih baik dibandingkan dengan kemampuan spasial siswa perempuan.

\section{REKOMENDASI}

Ada beberapa saran yang perlu mendapat perhatian dari berbagai pihak yaitu (1) penelitian ini hanya terbatas pada materi bangun ruang tiga dimensi saja, diharapkan penelitian lain dapat mengembangkan penelitian ini pada materi geometri yang lainnya. (2) peneliti juga bisa menemukan faktor gender pada kemampuan matematika lainnya.

\section{DAFTAR PUSTAKA}

Asis, dkk. (2015). Profil Kemampuan Spasial dalam Menyelesaikan Masalah Geometri Siswa yang Memiliki Kecerdasan Logis Matematis Tinggi Ditinjau dari Perbedaan Gender (Studi kasus di kelas XI SMAN 17 Makasar). Jurnal Daya Matematis, 3 (1), $78-87$

Battista, M.T. (1990). Spatial Visualization and Gender Differences in High School Geometry. Journal for Research in Mathematics Education.

Bratama. (1987). Pengertian-Pengertian Dasar dalam Pendidikan Luar biasa. Jakarta: Depdikbud.

Chatib, M. \& Said, A. (2012). Sekolah Anakanak Juara. Bandung: Penerbit Kaifa.

Creswell, J.W. (2010). Research Design : Pendekatan Kualitatif, Kuantitatif, dan mixed. Yogyakarta : Pustaka Pelajar

Barke dan Engide. (2001). Structural Chemistry and Spatial Ability in Different Cultures. Chemistry Education : Research and Practice in Europe, 2(3), 227 - 239

Bosnyak, A dan Rita, N.K. (2008). The Spatial Ability and Spatial Geometrical Knowledge Of University Students Majored In Mathematics. Acta Didactia Universitatis Comenianae, 8, $1-25$

Handayani, K., Sutriyono, Prihatnani, E. (2016). Perbedaan Kecerdasan Spasial Antara Siswa Laki-laki dan Siswa Perempuan Pada Kelas X SMA Negeri 1 
PRINSIP Pendidikan Matematika

Volume 2, Nomor 1, November 2019

Salatiga. Prosiding Seminar Nasional "Optimalisasi Active Learning dan Character Building dalam Meningkatkan Daya Saing Bangsa di Era Masyarakat Ekonomi ASEAN (MEA)”, 315 - 321.

Ismunanto. (2015). Ensiklopedia Matematika Jilad 6. Jakarta : PT. Lentera Abadi.

Kartono, K. (1989). Psikologi Wanita (Jilid 1): Mengenal Gadis Remaja dan Wanita Dewasa. Bandung : CV Mandar Maju.

Lestari, N.D.F. (2010). Profil Pemecahan Masalah Matematika Open-Ended Siswa Kelas V Sekolah Dasar Ditinjau dari Perbedaan Gender dan Kemampuan Matematika. Surabaya: Unesa.

Maccoby, E.E \& Jacklin, C.N. (1974). The Psychology of Sex Differences. Stanford: Stanford University.

Maier, P.H. (1998). Spatial geometry and spatial ability-How to make solid geometry solid?. Selected Papers from the Annual Conference of Didactics of Mathematics 1996, Osnabrueck, 63 - 75

Nafi'an, M.I. (2011). Kemampuan Siswa Dalam Menyelesaikan Soal Cerita Ditinjau Dari Gender Di Sekolah Dasar. Seminar Nasional Matematika dan Pendidikan Matematika, 571 - 577.

Nemeth, B. (2007). Measurement of The Development of Spatial Ability By Mental Cutting Test. Annales Mathematicae et Informaticae, 34, 123 128.
Orton, A. (1992). A Learning Mathematics: Issues, Theory and Practice. Great Britain: Redwood Books.

Purwanti, K.L. (2013). Perbedaan Gender Terhadap Kemampuan Berhitung Matematika Menggunakan Otak Kanan Pada Siswa Kelas I. Jurnal Sawwa, 9(1), $107-122$.

Simatwa, dan Enose, M.W. (2010). Piaget's Theoryof Intellectual Development and Its Implication for Instructional Management At Pre-Secodary School Level. Educational Research and Reviews, 5(7), 366 - 371.

Sugiyono. 2010. Statistika Untuk Penelitian. Bandung: Alfabeta

Syahputra, E. (2013). Peningkatan Kemampuan Spasial Siswa Melalui Penerapan Pembelajaran Matematika Realistik. Cakrawala Pendidikan, 3, 353 $-364$

Tambunan, S.M. (2006). Hubungan Antara Kemampuan Spasial Dengan Prestasi Belajar Matematika. Jurnal Makara Sosial Humaniora, 10(1), 27 - 32.

Windratie. (2014). Perbedaan Multitasking laki-laki dan perempuan. Jakarta: CNN. 